\title{
Organizational-economic model of formation of socio-commercial multifunctional complex in the construction of high-rise buildings
}

\author{
Ariadna Kirillova ${ }^{1 *}$ and Oksana O. Prytkova ${ }^{2}$ \\ ${ }^{1}$ Moscow state university of civil engineering, 129337, 26, Yaroslavskoye Shosse, Moscow, Russia \\ ${ }^{2}$ LLC "AVStroy",16a, Selskohozyaystvennaya street, Moscow, Russia
}

\begin{abstract}
The article is devoted to the features of the formation of the organizational and economic model of the construction of a sociocommercial multifunctional complex for high-rise construction. Authors have given examples of high-altitude multifunctional complexes in Moscow, analyzed the advantages and disadvantages in the implementation of multifunctional complexes, stressed the need for a holistic strategic approach, allowing to take into account the prospects for the development of the city and the creation of a comfortable living environment. Based on the analysis of multifunctional complexes features, a matrix of SWOT analysis was compiled. For the development of cities and improving the quality of life of the population, it is proposed to implement a new type of multifunctional complexes of a joint social and commercial direction, including, along with the implementation of office areas - schools, polyclinics, various sports facilities and cultural and leisure centers (theatrical, dance, studio, etc.). The approach proposed in the article for developing the model is based on a comparative evaluation of the multifunctional complex project of a social and commercial direction implemented at the expense of public-private partnership in the form of a concession agreement and a commercial multifunctional complex being built at the expense of the investor. It has been proved by calculations that the obtained indicators satisfy the conditions of expediency of the proposed organizational-economic model and the project of the social and commercial multifunctional complex is effective.
\end{abstract}

\section{Introduction}

High-rise construction is an important factor in the development and perspective direction of the Russian real estate market. Among the many advantages of high-rise construction, the most important is the effective use of urban areas, due to the high cost of land, its scarcity and demand for residential and commercial real estate.

The vast foreign experience accumulated in America, Japan, Korea and other countries is widely studied and applied in Russian practice. Moscow continues the trend for the development of high-rise construction. Currently in the capital there are several dozens of

*Corresponding author: kirillova_an@mail.ru 
modern residential complexes with a height of more than 100 meters, among them such projects as "Triumph Palace", "Tricolor", "Edelweiss", skyscrapers in MIBC "Moscow City". At the end of 2016 has began the construction of a new complex of residential skyscrapers "Neskuchny Home \& SPA". Five towers will have from 70 to 90 floors. The project is located on Leninsky Prospekt within walking distance of the Neskuchny Garden. In the stylobate part of the residential complex there will be shopping galleries, a fitness club, author's cuisine restaurants, a cafe, a medical center, a bakery, a fresh-water shop, an underground parking lot for more than 3.000 cars and much more. A kindergarten for 250 children, a 24-hour children's club and a center for the development of children's creativity will be organized for children. The main attraction is a SPA-complex with a panoramic swimming pool, located in the transition between the two towers at a level of 130 meters above the ground. At the initial stage of construction, prices for apartments start from $\$ 167200)$. In this case, the most expensive lot - penthouse area of 532 square meters - costs \$ 6.8 million High-rise construction is determined by the multicomponent, high degree of risk and capital intensity, complexity and multifunctionality. The construction of such multifunctional complexes (MFC) is aimed at the complex solution of important urban tasks for the development of housing stock, the creation of office centers, business parks, leisure facilities for residents and recreational areas, redevelopment of territories for the withdrawal of industrial zones from the city center, etc. $[1,3,4,5,11]$.

There are also drawbacks in the implementation of MFC, which are often due to inaccurate assessment of their potential, scale, insufficient validity of investment and credit decisions, lack of competitiveness of offered goods and services, and experience in effective operation. The effectiveness of MFC projects is also adversely affected by errors that are allowed when choosing the optimal ratio of the functional composition of the MFC and determining the optimal balance of areas in the complex, which leads to inconsistencies in various segments of real estate [12].

A holistic strategic approach is needed to take into account the development prospects of the city and create a comfortable living environment. At the same time, the strategic development of the MFC of the social and commercial direction should comply with the following principles:

-promote the development of the city in the long term and positively influence the development of specific urban areas and the city as a whole, ensure the formation of a favorable urban environment and improve the living conditions of citizens;

-ensure the development of urban areas by combining the efforts of private investors and the state;

-use specific mechanisms to regulate the problems that arise in the state and investors in the joint implementation of MFC projects [8].

At present, Russian experts refer to multifunctional complexes, mainly, projects with two or more functional components, each of which forms independent demand. Foreign experience on this topic shows that the MFC should consist of at least three incomeproducing components that generate revenue and have independent demand. Specialists note that these functions in the MFC are united by a single space or building in order to create the most comfortable environment, where the basic functions of the city's life will be realized. In the domestic practice there are two types of IFC: residential and commercial [9].

Residential MFC is a building or complex of residential buildings united by a common infrastructure and a single architectural concept. Such complexes fulfill the housing and social function. The public structure appears on the first floors, and the residential structure on the next floors.

Commercial IFC is a real estate object combining such categories as office, retail, hotel, etc. The most common in the Russian practice is the combination of office and retail real 
estate, with any ratio of areas. Also, recently, an increasing number of multifunctional complexes include a hotel function [10].

Based on the analysis of the characteristics of the MFC was compiled a matrix of SWOT analysis (Table 1). It analyzes the strengths and weaknesses of the MFC, as well as their capabilities and threats.

The investment attractiveness of multifunctional complexes directly depends on the economic efficiency of interconnected structures, premises, institutions into a single whole, a single real estate object that is limited to a specific territory.

Table 1. SWOT analysis of MFC

\begin{tabular}{|l|l|}
\hline \multicolumn{1}{|c|}{ Strengths of MFC } & \multicolumn{1}{|c|}{ Weaknesses of MFC } \\
\hline The maximum efficiency from the use of land. & $\begin{array}{l}\text { The emergence of difficulties in the design and } \\
\text { implementation of the project. }\end{array}$ \\
\hline Reducing the cost of resources. & $\begin{array}{l}\text { The possibility of a collision of functions with an } \\
\text { erroneous zoning and concept. }\end{array}$ \\
\hline $\begin{array}{l}\text { Reducing the unit cost of creating an object due } \\
\text { to its scale. }\end{array}$ & The most complex promotion of the object. \\
\hline $\begin{array}{l}\text { Multifunctionality of the complex increases } \\
\text { attendance. }\end{array}$ & $\begin{array}{l}\text { Specificity, greater complexity, cost of operation and } \\
\text { management of the object. }\end{array}$ \\
\hline $\begin{array}{l}\text { Synergetic effect due to the attendant functions, } \\
\text { which can complement each other with visitor } \\
\text { flows. }\end{array}$ & $\begin{array}{l}\text { When zoning the territory there may be restrictions on } \\
\text { the legislation. }\end{array}$ \\
\hline $\begin{array}{l}\text { The possibility of repeated use of free areas of } \\
\text { the IFC. }\end{array}$ & The need to maintain an object class. \\
\hline $\begin{array}{l}\text { Multifunctionality of the object increases the } \\
\text { investment attractiveness of the project, because } \\
\text { there is a reduction in risks due to investing in } \\
\text { different types of real estate. }\end{array}$ & $\begin{array}{l}\text { If there are apartussments in the MFC that lack the } \\
\text { social infrastructure necessary for human life. }\end{array}$ \\
\hline $\begin{array}{l}\text { The ability to re-profile the object in a variety of } \\
\text { adverse situations. }\end{array}$ & \multicolumn{1}{|c|}{ Capabilities } \\
\hline $\begin{array}{l}\text { Reorganization of industrial areas with a lack of } \\
\text { free space. }\end{array}$ & The general state of the Russian economy. \\
\hline $\begin{array}{l}\text { The emergence of legislative acts that regulate } \\
\text { the implementation of MFC projects. }\end{array}$ & Instability of the US dollar, euro. \\
\hline $\begin{array}{l}\text { Expansion of types of MFC (implementation of } \\
\text { the MFC socio-commercial direction). }\end{array}$ & Lack of free land in large cities. \\
\hline & Market oversaturation, lack of demand. \\
\hline
\end{tabular}

The quality of projects in the MFC in Russia lags far behind their number, this indicates their relative immaturity. It will take several years for the MFC segment to acquire the features of a civilized market. It is necessary to develop organizational and economic models for the implementation of MFC projects, expand the list of types of MFC, including through the appearance of the MFC socio-commercial function.

\section{Method and algorithm}

For the development of cities and improving the quality of life of the population, it is proposed to implement a new type of multifunctional complexes of a joint social and commercial direction, including, along with the implementation of office areas - schools, polyclinics, various sports facilities and cultural and leisure centers (theatrical, dance, studio, etc.). Earlier in the Russian practice, projects of this type were practically not implemented.

The essence of this proposal is that in one complex of buildings will be combined: school, polyclinic, sports and leisure facilities, so children who will study at this school will be able to visit sports (pool, sports grounds, arenas, gyms, etc.) and leisure institutions (theatrical, 
dance, art, music studios) without spending too much time as it usually happens now. Parents, in order to educate and diversify their children, lead them to various education centers. In terms of the magnitude of megacities, it needs a huge time and resources.

The combination of these functions in a single high-rise building will increase the economic efficiency of the use of space by combining the premises of various activities [10].

Organizational models of MFC project implementation are formed on the basis of the project management model simultaneously in several directions: design, construction management, operation, including facility management (operation organization, relationships with related organizations and suppliers, all types of work with tenants), repair of building structures, engineering systems of facilities (inspections, monitoring, preparation for seasonal operation, current and major repairs), the sanitary maintenance (cleaning of places of the general using, cleaning of adjacent territories, care of green plantations) [8.9].

Economic models of MFC implementation are formed on the basis of project financing methods. It refers to the financing of investment projects, which is characterized by a special way to ensure return on investment, which is based on the investment quality of the project itself, the revenues received from the company being created or reconstructed in the future. A special mechanism for project financing includes an analysis of the technical and economic characteristics of the investment project and an assessment of the risks that are associated with it, and the return on investment is based on project revenues that remain after covering all financial expenditures $[13,14]$. Financing of real estate projects is carried out by the developer's own funds or borrowed. Using a developer or builder borrowed funds in the Russian market, namely, a bank loan in practice is associated with: insufficiency of the developer's own funds, need to provide the bank with sufficient security, lack of opportunities for Russian banks to lend investment and construction projects in sufficient quantities and for a specific time frame. In these circumstances, when constricrion and operating the MFC, it is advisable to apply the mechanisms of public-private and municipal-private partnership $[2,6,15]$. One of the main priorities of state policy is the construction of socially important facilities. The proposed MFC project, being socially significant, will have the following functions: educational, sports, cultural, wellness and office. The economic model will be formed by combining state and private financing, i.e. a model of public-private partnership (PPP) is applied. The proposed type of MFC is presented in the following scheme (Figure 1).

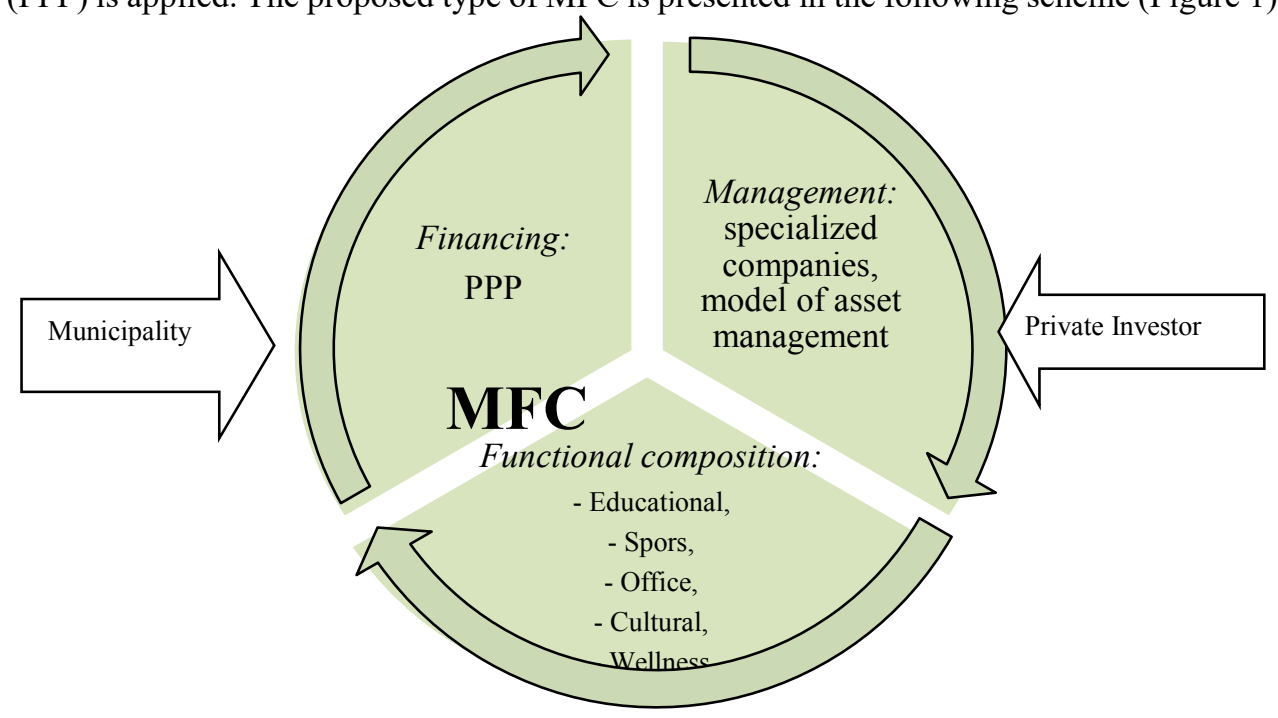

Fig. 1. Methodological approaches to the organizational-economic model of MFC 
School and polyclinic in this MFC will be public (free), sports and cultural facilities paid. Accordingly, the school and polyclinic should be financed by the municipality, sports and cultural facilities - by private investors. Since all these blocks should function interconnected in one real estate object, the author is invited to implement the MFC of the social and commercial direction (Table 2) using the following organizational and economic model.

Table 2. Functional components of the socio-commercial MFC

\begin{tabular}{|l|l|l|l|}
\hline \multicolumn{1}{|c|}{ Functions } & \multicolumn{1}{|c|}{ Function blocks } & Management & \multicolumn{1}{|c|}{ Financing } \\
\hline Educational & $\begin{array}{l}\text { Educational institution } \\
\text { (school) }\end{array}$ & Municipality & $\begin{array}{l}\text { Means of the } \\
\text { municipality }\end{array}$ \\
\hline Sports & $\begin{array}{l}\text { Paid sports facilities } \\
\text { (swimming pool, sports } \\
\text { grounds, playpens, gyms, } \\
\text { etc.) }\end{array}$ & Private owner & $\begin{array}{l}\text { Private and loan } \\
\text { investments }\end{array}$ \\
\hline Cultural & $\begin{array}{l}\text { Paid cultural and leisure } \\
\text { centers (theater, dance, art, } \\
\text { music studios) }\end{array}$ & Private owner & $\begin{array}{l}\text { Private and loan } \\
\text { investments }\end{array}$ \\
\hline Wellness & Polyclinic & Municipality & $\begin{array}{l}\text { Means of the } \\
\text { municipality }\end{array}$ \\
\hline Office & Office area in rent & Private owner & $\begin{array}{l}\text { Private and loan } \\
\text { investments }\end{array}$ \\
\hline
\end{tabular}

\section{Results}

To select from the possible alternative combinations of functional modules of the most optimal, socially significant and profitable MFC project that will meet the investor and city requirements, an algorithm for modeling the MFC project of a social and commercial direction in Moscow is proposed, as well as a comparison with the concept of implementing a typical MFC project. This algorithm will make it possible to clearly identify the best and most effective solutions for both the investor and the municipality. The algorithm is shown in Fig. 3.

The proposed approach to the development of the model is based on a comparative evaluation of the MFC project of the social and commercial direction implemented through PPP in the form of a concession agreement and a commercial MFC being built at the expense of the investor. The question of the legal relationship to the land plot will be decided in completely different ways. When implementing a commercial MFC, the land plot will be leased, which means that the item "Lease of the land plot" will appear in the cost structure. When the MFC realizes a social and commercial direction, a concession agreement will be concluded between the investor and the municipality, according to which the land plot will be granted to the investor by the municipality for free use for a certain period, which will correspond to the payback period of the project and the receipt of profit for the investor. Therefore, in the costs of implementing the socio-commercial MFC, there are no costs associated with leasing or buying a land plot. 

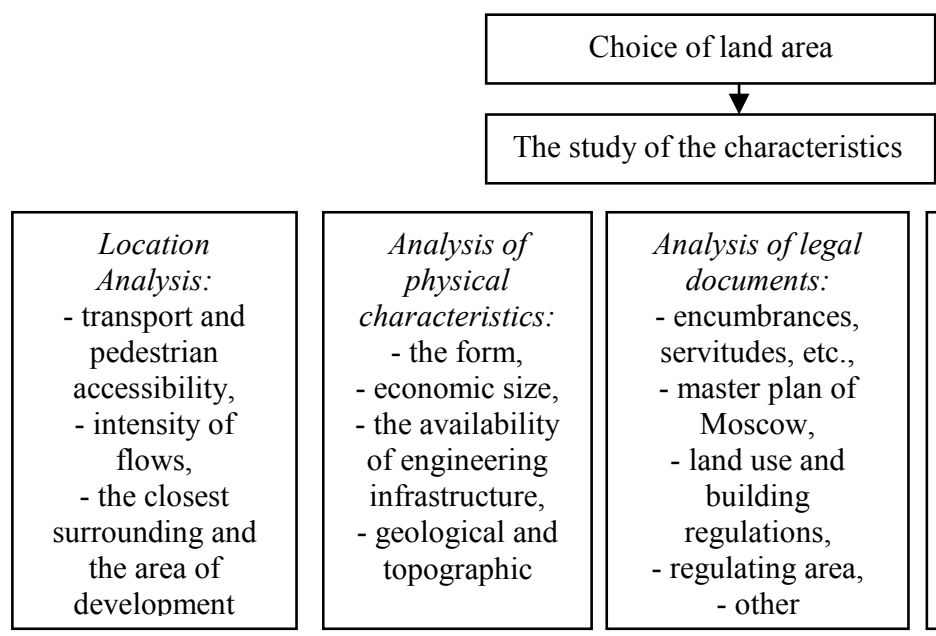

\begin{tabular}{|c|}
\hline Analysis of \\
physical \\
characteristics: \\
- the form, \\
- economic size, \\
- the availability \\
of engineering \\
infrastructure, \\
- geological and \\
topographic \\
\hline
\end{tabular}

\begin{tabular}{c} 
Analysis of legal \\
documents: \\
- encumbrances, \\
servitudes, etc., \\
- master plan of \\
Moscow, \\
- land use and \\
building \\
regulations, \\
- regulating area, \\
- other \\
\hline
\end{tabular}

\begin{tabular}{|c|}
\hline Analysis of market \\
demand: \\
- analysis of target \\
segments of the real \\
estate market, \\
- marketing and \\
social studies and \\
forecasts, \\
- analysis of demand \\
for each type of space \\
used. \\
\hline
\end{tabular}

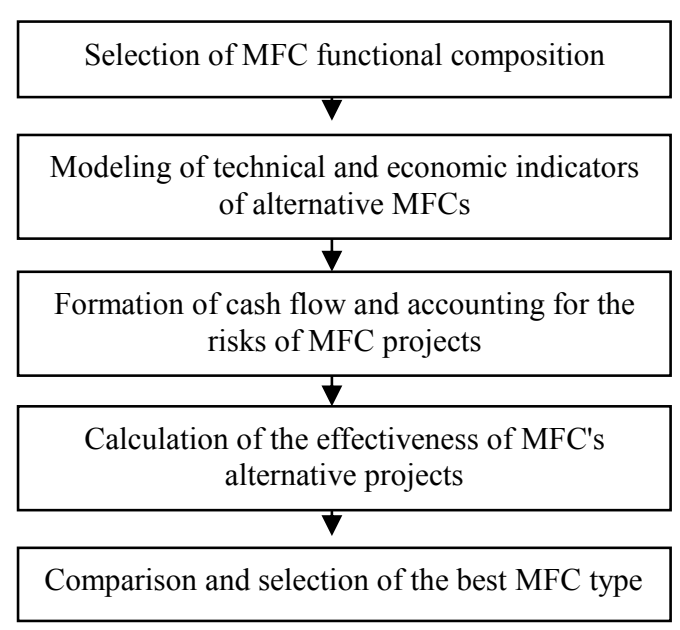

Fig. 3. Algorithm for modeling the MFC project in the city

The main income of a commercial MFC consists of leased space, apartments, parking spaces, and sales areas. In the social and commercial MFC, revenues are derived from the rental of offices, areas for the sports and cultural and leisure sector, as well as rental of parking spaces. Table 3 compares the obtained indicators of commercial efficiency of two projects.

Table 3. Comparative performance indicators of MFC

\begin{tabular}{|c|c|c|}
\hline \multicolumn{1}{|c|}{ Indicator } & Commercial MFC & Socio-commercial MFC \\
\hline Internal rate of return (IRR) & $3.9 \%$ & $2.4 \%$ \\
\hline Internal rate of return (IRR), \% per annum & $46.2 \%$ & $28.8 \%$ \\
\hline Present value of cash flows, USD & 22134316604 & 9787739698 \\
\hline Net present value (NPV), USD & 220488311 & 201236861 \\
\hline Profitability index (PI) & 1.84 & 1.54 \\
\hline Payback period (PBP), months. & 70 & 70 \\
\hline Discounted payback period (DPBP), months. & 72 & 73 \\
\hline
\end{tabular}


From the results obtained, it follows that the calculated indicators of the commercial MFC are significantly higher than the socio-commercial MFC. This is due to the fact that in the commercial MFC revenues come from the entire constructed area of the MFC, unlike another MFC, where part of the building area is given to a school and a budgetary polyclinic, and the rest of the premises are profitable. All received indicators satisfy the condition of the proposed model and the social and commercial MFC is effective.

\section{Conclusions}

One of the effective tools for improving the spatial structure of cities can be high-rise multifunctional complexes that play the role of an effective management tool for the territorial development of real estate. The advantages of the project implementation are the effectiveness of children's education, transport unloading, walking accessibility of services and increasing the investment attractiveness of the surrounding buildings. The implementation of this MFC is not only a means of profit for the developer, but also has a significant impact on the city budget, economic and social relations, which will certainly improve the living standards of citizens, improve the quality and diversity of the urban environment.

\section{References}

1. Urban Development Code of the Russian Federation. Official text (Moscow, Prospekt, Omega-L) 104 (2009)

2. Federal Law of the Russian Federation of July 21, 2005 No. 115-FZ "On Concession Agreements" (2005)

3. Federal Law of 25.02.1999 No. 39-FZ "On investment activities in the Russian Federation, implemented in the form of capital investments" (1999)

4. Law of the City of Moscow of March 3, 2004 No. 13 "On the Basics of Urban Development in the City of Moscow" (2004)

5. Moscow City Building Codes 4.04-94 "Multifunctional buildings and complexes" (1994)

6. O.Yu. Atkov, Options for business and state cooperation for the development and improvement of social infrastructure: the prospects for using PPP mechanisms (Moscow) (2008)

7. N.F. Vecher, A.A. Olkhlvsky, Investments in commercial real estate. Life cycle of the facility (Moscow: Business project) (2005)

8. T.A. Osipova, Formation of a strategy for the development of multifunctional complexes in a large city, $\mathrm{PhD}$ Thesis (2012)

9. P.G. Graboviy, S.I. Beliakov, A.N. Kirillova \& other, Surveying: organization, expertise, management. Part two. Expertise of real estate and construction control (Moscow, ASV, Prosvetitel, 2015)

10. P.G. Graboviy, S.I. Beliakov \& other, Economics and real estate management (Moscow, Prospekt, 2013)

11. V.M. Ostretsov The proceedings of the annual city conference-exhibition"Unique and special technologies in construction of UST-Build 2004 (Moscow) (2004).

12. R.I. Ibragimov, E.P. Kotelnikova, M.A. Morozov, A.A. Sutugin, Main problems of construction of height buildings, Scientific and Practical Electronic Journal of the Alley of Science 9 (2017) 
13. D.L. Whitley, Genetic Algorithms and Evolutionary Computing (Van Nostrand's Scientific Encyclopedia) (2002)

14. I. Chamey Igal, The conditions for capital investment in the real estate, University of Toronto, PhD Thesis (2000)

15. G. Ian. Thrall, Business geography and new real estate market analysis (NC, USA, Oxford University Press, Incorporated) (2002) 